Abstracta Iranica Abstracta Iranica

Revue bibliographique pour le domaine irano-aryen

Volume 23 | 2002

Comptes rendus des publications de $\mathbf{2 0 0 0}$

\title{
Die iranischen Sprachen in Geschichte und Gegenwart. Wiesbaden, Reichert Verlag, 2000, IX + 106 p., 1 carte.
}

Philip Huyse

\section{(2) OpenEdition}

1 Journals

Édition électronique

URL : http://journals.openedition.org/abstractairanica/35151

DOI : $10.4000 /$ abstractairanica.35151

ISSN : 1961-960X

Éditeur :

CNRS (UMR 7528 Mondes iraniens et indiens), Éditions de l'IFRI

\section{Édition imprimée}

Date de publication : 15 mai 2002

ISSN : 0240-8910

\section{Référence électronique}

Philip Huyse, "Die iranischen Sprachen in Geschichte und Gegenwart. Wiesbaden, Reichert Verlag, 2000, IX + 106 p., 1 carte. », Abstracta Iranica [En ligne], Volume 23|2002, document 23, mis en ligne le 08 février 2010, consulté le 25 septembre 2020. URL : http://journals.openedition.org/abstractairanica/ 35151 ; DOI : https://doi.org/10.4000/abstractairanica.35151

Ce document a été généré automatiquement le 25 septembre 2020.

Tous droits réservés 


\title{
Die iranischen Sprachen in Geschichte und Gegenwart. Wiesbaden, Reichert Verlag, 2000, IX + 106 p., 1 carte.
}

\author{
Philip Huyse
}

1 Ce petit recueil s'adressant à un public non-spécialiste donne un aperçu des langues iraniennes depuis l'époque la plus reculée jusqu'à l'iranien contemporain. Il reprend une série de cinq articles parus entre 1995 et 1998 dans une revue du service culturel de l'ambassade iranienne en Allemagne. Les articles condensent le contenu beaucoup plus détaillé de l'ouvrage Compendium Linguarum Iranicarum, Wiesbaden, 1989, publié par le même auteur. On regrette seulement qu'un tel ouvrage récent n'existe pas en français, d'autant plus que la traduction française par Joyce Blau, du livre russe de Iosif M. Oranskij Les langues iraniennes (Paris, 1977) est maintenant largement dépassée.

\section{INDEX}

Thèmes : 2.1. Langues anciennes

\section{AUTEURS}

PHILIP HUYSE

CNRS - Paris 